\title{
MENINGKATKAN HASIL BELAJAR SISWA DENGAN MENGGUNAKAN MEDIA AUDIO PADA MATA PELAJARAN PPKn DI KELAS VIII SMP NEGERI 1 TIGAPANAH TAHUN PELAJARAN 2018/2019
}

OLEH:

KARMILA BR KARO

(UNIVERSITAS QUALITY)

\begin{abstract}
The kind of this research is classroom action research utilizing audio in PPKn. The aim in this research are to describe the mastery of student learning and student learning outcomes utilizing audio media in PPKn at SMP Negeri 1 Tigapanah in the second semester of academic year of 2018/2019. This classroom action research consists of two cycles, consists of phases: planning, implementation, evaluating and reflection. First cycle utilizing audio, second cycle utilizing audio media too. The subject of this research uses one class as research sample, all students of grade VIII in the second semester of academic year of 2018/2019 which amounted to 20 student.

First cycle implementation, data obtained that amount of students who completed individually are 15 student and not completed individually are 5 student, while students complete classically is $75 \%$ and students not complete classically is $25 \%$, and the average value is $60,1 \%$. Second cycle implementation, data obtained that amount of students who completed individually are 18 student and not completed individually are 2 student, while students complete classically is $90 \%$ and students not complete classically is $5 \%$, and the average value is 77,4 $\%$.

Based on the results of data analysis, it can be concluded that the implementation of learning using audio media has been categorized as good, mastery learning is achieved and student learning outcomes increase in PPKn subjects in class VIII SMP Negeri 1 Tigapanah Tahun Pelajaran 2018/2019
\end{abstract}

\section{Keyword: learning outcomes, utilizing audio media}

\section{PENDAHULUAN}

Proses pembelajaran melibatkan guru dan peserta didik. Guru harus mampu menggunakan strategi, metode, model dan pendekatan. Selain itu, guru harus mampu menguasai media yang harus di sesuaikan dengan materi yang akan disampaikan oleh guru. Media juga sangat berpengaruh dalam pemahaman siswa dalam memahami suatu materi pelajaran. Media yang sesuai dengan materi pembelajaran tentunya akan sangat membantu guru dalam menjelaskan 
pembelajaran. Media pembelajaran biasanya dapat berupa bentuk visual dan audio visual. Bentuk dari media visual dapat berupa gambar, diagram, dan lain sebagainya dan bentuk dari media audio visual dapat berupa rekaman video, rekaman suara, radio dan lain sebagainya.

Salah satu mata pelajaran yang jarang menggunakan media adalah pembelajaran PPKn. Pembelajaran ini sering kali dianggap sulit dan lebih membosankan dibandingkan dengan pelajaran-pelajaran lainnya. Pembelajaran PPKn seharusnya membuahkan hasil belajar berupa pengetahuan, sikap dan keterampilan yang sejalan dengan tujuan kurikulum pendidikan nasional. Tujuan dari pembelajaran PPKn adalah agar para siswa mampu untuk membaca dan memperluas wawasan mereka sesuai dengan nilai-nilai Pancasila dan menjadi warga Negara yang baik., namun dalam kenyataannya yang terjadi di dalam proses pembelajaran yang berlangsung di sekolah adalah siswa kurang memahami tujuan yang hendak di capai.

Hal yang sama juga terjadi terhadap siswa dan siswi di Kelas VIII SMP Negeri 1 Tigapanah. Hal itu terlihat saat proses belajar mengajar berlangsung siswa kurang memperhatikan penjelasan guru. Siswa mudah teralihkan perhatiannya dengan apa yang ada di luar kelas sehingga sulit untuk berkosentrasi saat belajar. Berdasarkan daftar nilai mata pelajaran PPKn khususnya dalam pembelajaran menyimak ternyata hasil belajar siswa masih dalam kategori belum memuaskan.

Penelitian tindakan kelas ini dilakukan berdasarkan latar belakang masalah yang diuraikan diatas. Dengan itu, untuk mengatasi masalah-masalah tersebut guru perlu menggunakan metode dan media pembelajaran yang bervariasi. Salah 
satu upaya untuk meningkatkan hasil belajar siswa adalah dengan menggunakan media Audio. Media pembelajaran audio adalah jenis media yang digunakan dalam pembelajaran dengan melibatkan pendengaran dan dalam kegiatan atau proses belajar. Fungsinya untuk meningkatkan kemampuan anak untuk menyimak suatu pembelajaran Untuk itu penulis memutuskan untuk melakukan penelitian tindakan kelas dengan judul "Meningkatkan Hasil Belajar Siswa Dengan Menggunakan Media Audio Pada Mata Pelajaran PPKn Di Kelas VIII SMP Negeri 1 Tigapanah Tahun Pelajaran 2018/2019”

Tujuan penelitian ini adalah untuk mengetahui ketuntasan hasil belajar siswa dengan menggunakan Media Audio pada Mata pelajaran PPKn di Kelas VIII SMP Negeri 1 Tigapanah Tahun Pelajaran 2018/2019 dan untuk mengetahui hasil belajar siswa meningkat Menggunakan Media Audio pada Mata pelajaran PPKn di Kelas VIII SMP Negeri 1 Tigapanah Tahun Pelajaran 2018/2019. Diharapkan penelitian ini dapat sebagai bahan masukan bagi guru dalam meningkatkan hasil belajar siswa dan menambah keterampilan guru dalam meningkatkan kualitas pengajaran dengan menggunakan media Audio.

\section{METODE PENELITIAN}

Penelitian dilaksanakan di SMP Negeri 1 Tigapanah. Subjek pada penelitian ini adalah siswa VIII SMP Negeri 1 Tigapanah Tahun Pelajaran 2018/2019 berjumlah 20 orang siswa. Adapun objek penelitian ini adalah perbaikan pembelajaran dengan menggunakan Media Audio dalam mata pelajaran PPKn. Jenis penelitian yang dilakukan adalah jenis penelitian dalam bentuk Penelitian Tindakan Kelas (PTK). Dengan ciri khas yaitu dilaksanakannya dengan 
menggunakan siklus-siklus yang merupakan suatu pemecahan menuju praktek pembelajaran yang lebih baik, tiap pelaksanaan pembelajaran terdiri dari perencanaan ,pelaksanaan, tindakan, observasi dan refleksi.

Desain penelitian yang digunakan dalam penelitian tindakan kelas berupa refleksi awal dan observasi untuk mengindentifikasi permasalahan yang terjadi di kelas, dilanjutkan dengan pelaksanaan Penelitian Tindakan Kelas (PTK).

Secara garis besar terdapat empat tahapan yang dilalui dalam pelaksanaan penelitian tindakan kelas, yaitu (1) perencanaan, (2) pelaksanaan, (3) pengamatan, dan (4) refleksi.

\section{HASIL PENELITIAN}

Dari hasil pelaksanaan perbaikan pembelajaran yang dilaksanakan dengan Media Audio pada pembelajaran PPKn dapat meningkatkan hasil belajar siswa Kelas VIII SMP Negeri 1 Tigapanah Tahun Pelajaran 2018/2019 dengan subjek penelitian sebanyak 20 orang siswa diperoleh:

\section{Ketuntasan Belajar Siswa Secara Individu Siklus I dan II}

Berdasarkan hasil tes yang diberikan kepada siswa setelah pembelajaran siklus I dan siklus II dapat dilihat pada tabel 1 berikut :

Tabel 1. Ketuntasan Hasil Belajar Siswa secara Individu Siklus I dan II

\begin{tabular}{|l|l|c|c|c|}
\hline No & Hasil Belajar Siswa & Siklus I & Siklus II & Keterangan \\
\hline 1 & Siswa yang tidak tuntas & 5 & 2 & \\
\hline 2 & Siswa yang tuntas & 15 & 18 & Meningkat \\
\hline
\end{tabular}


Berdasarkan tabel di atas dapat diketahui bahwa ketuntasan Hasil belajar siswa pada siklus I yang dipaparkan oleh table, bahwa siswa yang tuntas atau mendapat nilai $\geq 60$ hanya sebanyak 15 orang siswa dari 20 orang siswa dan 5 orang siswa yang tidak tuntas. Ketuntasan hasil belajar siswa secara individu pada siklus II diperoleh 18 orang siswa yang tuntas belajar dan 2 orang siswa yang tidak tuntas. Berdasarkan data ketuntasan individu siklus I dan siklus II diketahui bahwa ketuntasan individu siklus I dan Siklus II diketahui bahwa ketuntasan siswa secara individu meningkat. Berdasarkan data ketuntasan siswa secara individu pada tabel 1 di atas maka digambarkan dalam diagram batang sebagai berikut:

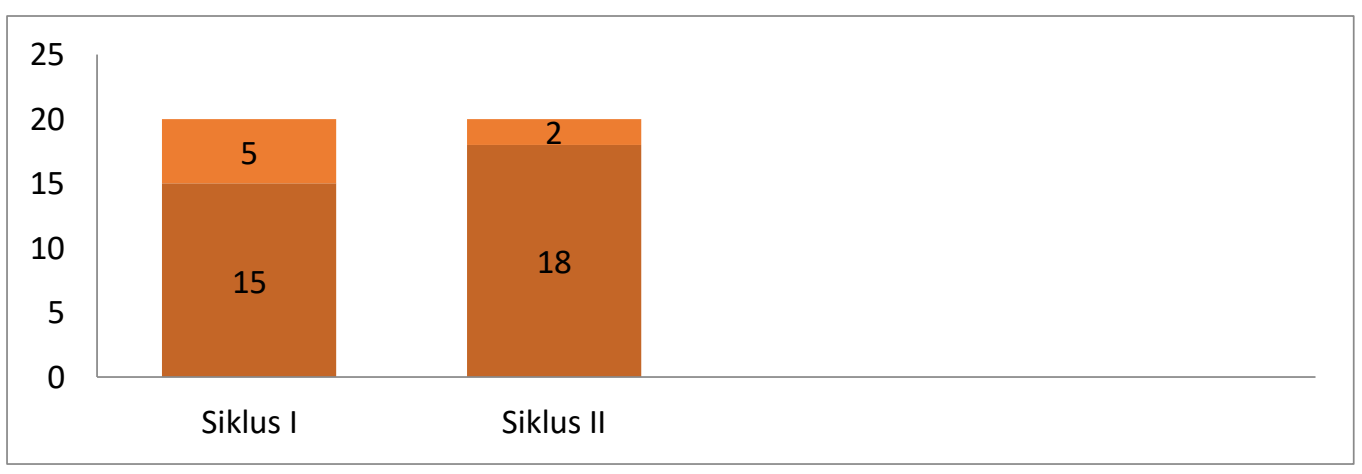

\section{Ketuntasan Belajar Siswa Secara Klasikal Siklus I dan II}

Berdasarkan hasil tes yang diberikan kepada siswa setelah pembelajaran siklus I dan siklus II dapat dilihat pada tabel 2 berikut :

Tabel 2. Ketuntasan Hasil Belajar Siswa secara Klasikal Siklus I dan II

\begin{tabular}{|c|l|c|c|c|}
\hline No & Hasil Belajar Siswa & Siklus I & Siklus II & Keterangan \\
\hline 1 & Siswa yang tidak tuntas & $5(25)$ & $2(10)$ & \\
\cline { 1 - 3 } 2 & Siswa yang tuntas & $15(75)$ & $18(90)$ & \multirow{2}{*}{ Meningkat } \\
\hline
\end{tabular}

Berdasarkan tabel 2 di atas dapat diketahui bahwa ketuntasan Hasil belajar siswa pada siklus I yang dipaparkan oleh table, bahwa siswa yang tuntas atau 
mendapat nilai $\geq 60$ hanya sebanyak $15(75 \%$ ) orang siswa dari 20 orang siswa dan $5(25 \%)$ orang siswa yang tidak tuntas. Ketuntasan hasil belajar siswa secara klasikal pada siklus II diperoleh 18 ( $90 \%$ ) orang siswa yang tuntas belajar dan 2( $10 \%$ ) orang siswa yang tidak tuntas. Berdasarkan data ketuntasan individu siklus I dan siklus II diketahui bahwa ketuntasan klasikal meningkat. Berdasarkan data ketuntasan siswa secara klasikal pada tabel 4.21 di atas maka digambarkan dalam diagram batang sebagai berikut:

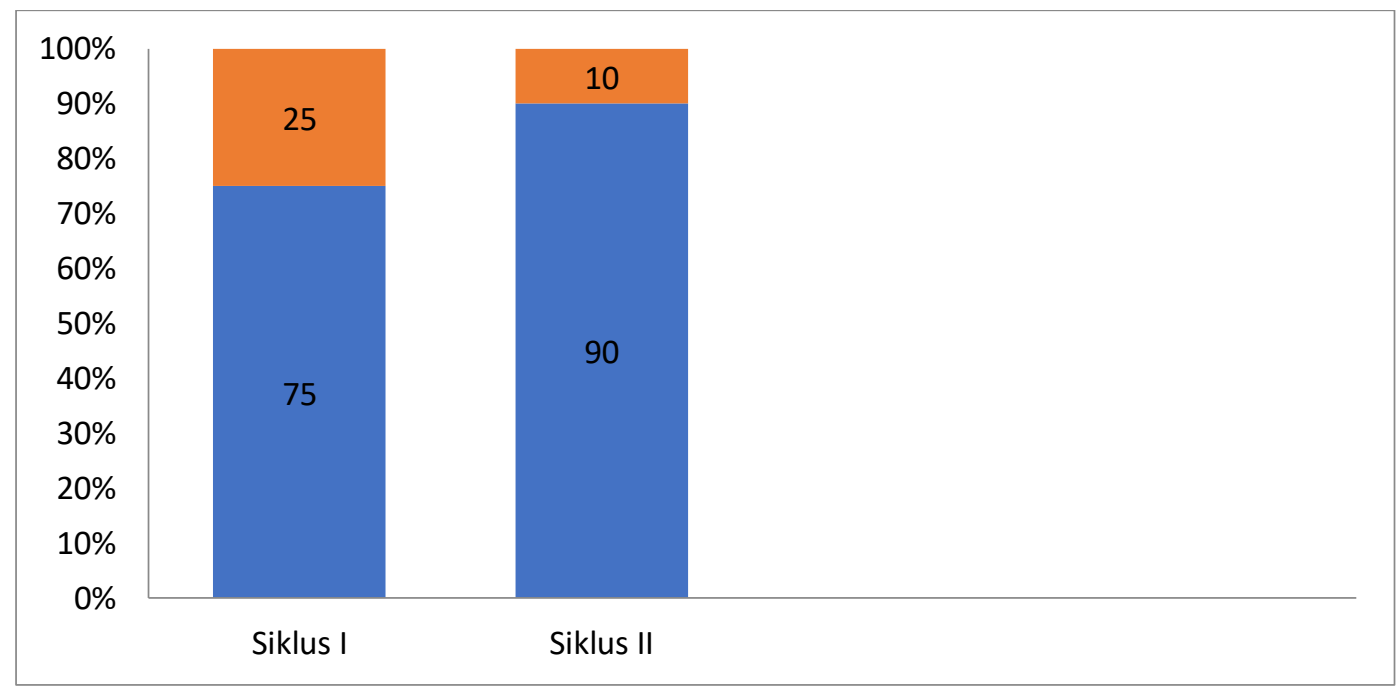

\section{Diagram Ketuntasan Hasil Belajar Siswa Secara Klasikal Siklus I dan II}

\section{Rata-rata Hasil Belajar Siswa Siklus I dan II}

Berdasarkan hasil tes belajar yang diberikan kepada siswa setelah pembelajaran siklus I dan siklus II maka dapat ditentukan nilai rata-rata siswa yang dapat dilihat pada tabel 3 berikut :

Tabel 3 Rata-rata Hasil Belajar Siswa Siklus I dan II

\begin{tabular}{|l|l|l|l|}
\hline No & \multicolumn{1}{|c|}{ Nilai } & \multicolumn{1}{|c|}{ Siklus I } & Keterangan \\
\hline 1 & Siklus I & 60.135 & \\
\hline 2 & Siklus II & 77.41 & Meningkat \\
\hline
\end{tabular}


Berdasarkan tabel 3 di atas dapat diketahui bahwa rata-rata hasil belajar siswa pada siklus I adalah 60.1 sedangkan pada siklus II diperoleh nilai rata-rata hasil belajar siswa yaitu 77.4. Hasil data pada tabel 3 dapat dilihat pada diagram batang berikut ini :

\section{Gambar 4.13 Diagram Peningkatan Rata-rata Hasil Belajar Siswa Siklus I dan Siklus II}

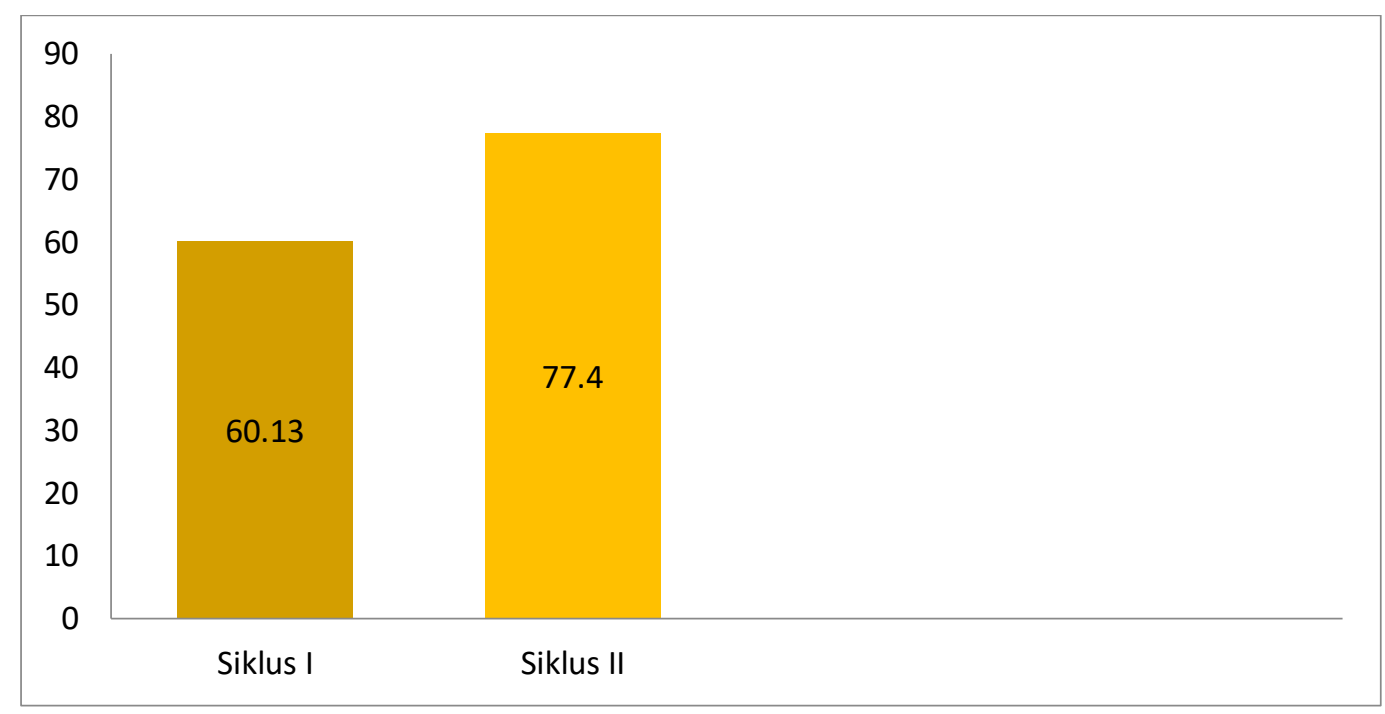

Berdasarkan Tabel 3 diperoleh data pada siklus II dengan menggunakan

Media Audio nilai rata-rata belajar siswa pada Siklus I adalah 60.1 sedangkan pada Siklus II nilai rata-rata belajar siswa adalah 77.4

Sehingga diperoleh hasil persentase peningkatan hasil belajar siswa:

Persentase Peningkatan Hasil Belajar Siswa $=\frac{\overline{\mathbf{x}} \text { Siklus II }-\overline{\mathbf{x}} \text { Siklus I }}{\overline{\mathbf{x}} \text { Siklus I }} \times 100 \%$

$$
\begin{aligned}
& =\frac{77.4-60.135}{60.135} \times 100 \\
& =\frac{17.27}{60.135} \times 100 \\
& =28.61 \%
\end{aligned}
$$


Untuk melihat peningkatan hasil belajar siswa dapat dilihat pada gambar berikut:

Gambar 4.14. Diagram Peningkatan Rata-rata Hasil Belajar Siswa Siklus I dan Siklus II

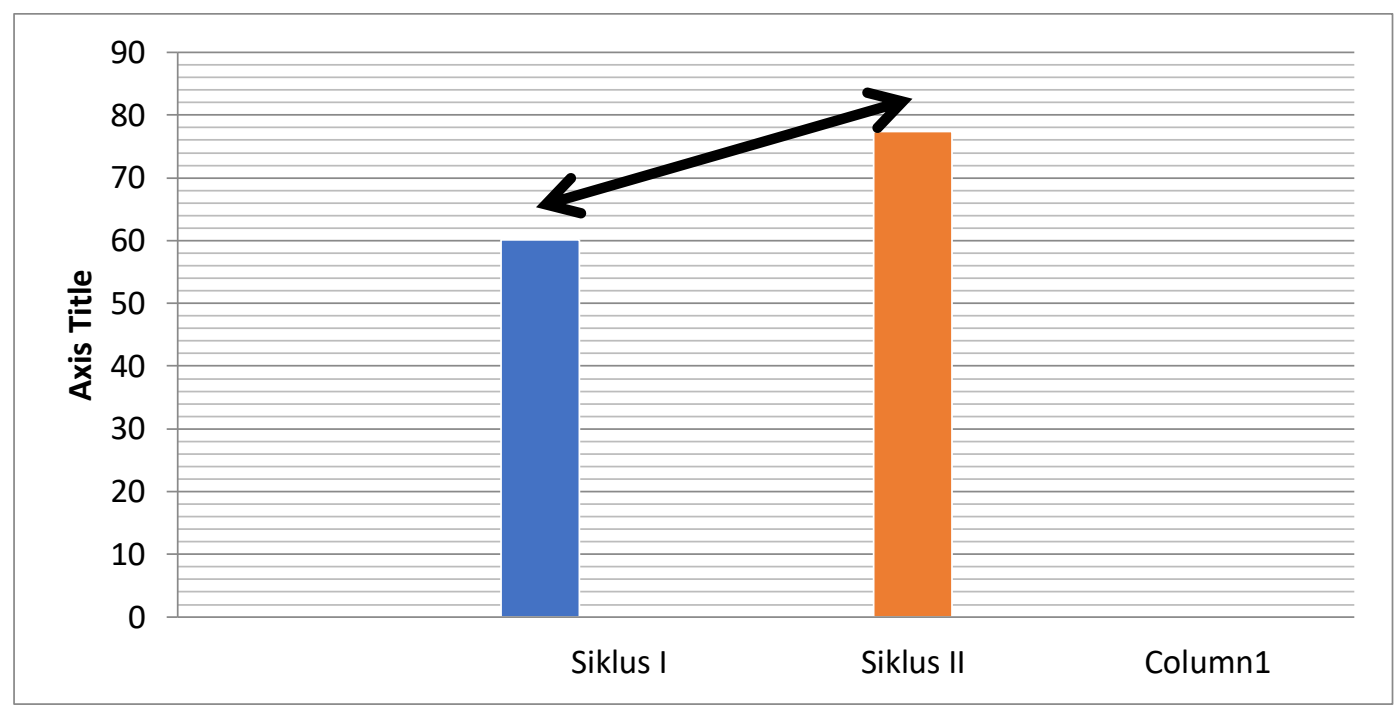

Berdasarkan penelitian ini menyatakan hasil belajar siswa meningkat dengan menggunakan Media Audio pada PPKn Kelas VIII SMP Negeri 1 Tigapanah Tahun Pelajaran 2018/2019 dapat disimpulkan dalam tabel 4 yaitu:

Tabel 4

Rekapitulasi Data Hasil Penelitian Siklus I dan II

\begin{tabular}{|l|c|c|}
\hline \multicolumn{1}{|c|}{ Data } & Siklus I & Siklus II \\
\hline Ketuntasan Hasil Belajar & 15 \\
\hline a. Tuntas Individu & $75 \%$ & $90 \%$ \\
\hline b. Tuntas Klasikal & 60.135 & 77.4 \\
\hline Rata-rata Hasil Belajar & \\
\hline a. Nilai Rata-rata & $28.61 \%$ \\
\hline b. Peningkatan Hasil Belajar Siklus I dan II & \\
\hline
\end{tabular}


Berdasarkan penelitian yang telah dilakukan oleh peneliti, hipotesis tindakan yang diajukan dalam penelitian ini yaitu, "dengan menggunakan media audio pada mata pelajaran PPKn terhadap siswa Kelas VIII SMP Negeri 1 Tigapanah Tahun Pelajaran 2018/2019 dapat diterima”.

\section{Tabel 5}

Rekapitulasi Hasil Belajar Siswa Siklus I dan Siklus II

\begin{tabular}{|c|c|c|c|c|}
\hline \multirow[b]{2}{*}{ No } & \multirow[b]{2}{*}{ Nama } & \multicolumn{2}{|c|}{ Nilai } & \multirow[b]{2}{*}{ Ketuntasan } \\
\hline & & Siklus I & Siklus II & \\
\hline 1 & Siswa 1 & 80 & 100 & Tuntas,Meningkat \\
\hline 2 & Siswa 2 & 37.7 & 62.2 & Tuntas,Meningkat \\
\hline 3 & Siswa 3 & 22.2 & 44.4 & Tidak Tuntas, Meningkat \\
\hline 4 & Siswa 4 & 71.7 & 80 & Tuntas,Meningkat \\
\hline 5 & Siswa 5 & 71.7 & 80 & Tuntas,Meningkat \\
\hline 6 & Siswa 6 & 33.3 & 80 & Tuntas,Meningkat \\
\hline 7 & Siswa 7 & 80 & 75.5 & Tuntas,menurun \\
\hline 8 & Siswa 8 & 26.6 & 100 & Tuntas,Meningkat \\
\hline 9 & Siswa 9 & 80 & 100 & Tuntas, Meningkat \\
\hline 10 & Siswa 10 & 33.3 & 55.5 & Tidak Tuntas, Meningkat \\
\hline 11 & Siswa 11 & 62.2 & 88.8 & Tuntas, Meningkat \\
\hline 12 & Siswa 12 & 75.5 & 84.4 & Tuntas,Meningkat \\
\hline 13 & Siswa 13 & 66.6 & 77.7 & Tuntas, Meningkat \\
\hline 14 & Siswa 14 & 62.2 & 77.7 & Tuntas, Meningkat \\
\hline 15 & Siswa 15 & 62.2 & 64.4 & Tuntas, Meningkat \\
\hline 16 & Siswa 16 & 66.6 & 62.2 & Tuntas, Menurun \\
\hline 17 & Siswa 17 & 62.2 & 62.2 & Tuntas,Tetap \\
\hline 18 & Siswa 18 & 75.5 & 100 & Tuntas, Meningkat \\
\hline 19 & Siswa 19 & 64.4 & 77.7 & Tuntas, Meningkat \\
\hline 20 & Siswa 20 & 68.8 & 75.5 & Tuntas, Meningkat \\
\hline & Jumlah & 1202.7 & 1548.2 & Meningkat \\
\hline & Rata-Rata & 60.7 & 77.4 & Meningkat \\
\hline & Ketuntasan & 15 & 18 & Meningkat \\
\hline & & 75 & 90 & Meningkat \\
\hline
\end{tabular}


Tabel 6

Rekapitulasi Hasil Belajar Siswa Siklus I dan Siklus II Berdasarkan Tingkat Pencapaian pada Siklus II

\begin{tabular}{|l|l|l|l|l|}
\hline \multirow{2}{*}{ No } & Nama & & Nilai & Ketuntasan \\
\cline { 3 - 5 } & & Siklus I & Siklus II & \\
\hline 1 & Siswa 1 & 80 & 100 & Tuntas / Meningkat \\
\hline 2 & Siswa 2 & 80 & 100 & Tuntas / Meningkat \\
\hline 3 & Siswa 3 & 75.5 & 100 & Tuntas / Meningkat \\
\hline 4 & Siswa 4 & 64.4 & 100 & Tuntas / Meningkat \\
\hline 5 & Siswa 5 & 62.2 & 88.8 & Tuntas / Meningkat \\
\hline 6 & Siswa 6 & 75.5 & 84.4 & Tuntas / Meningkat \\
\hline 7 & Siswa 7 & 71.7 & 80 & Tuntas / Meningkat \\
\hline 8 & Siswa 8 & 71.7 & 80 & Tuntas / Meningkat \\
\hline 9 & Siswa 9 & 33.3 & 80 & Tuntas / Meningkat \\
\hline 10 & Siswa 10 & 66.6 & 77.7 & Tuntas / Meningkat \\
\hline 11 & Siswa 11 & 26.6 & 77.7 & Tuntas / Meningkat \\
\hline 12 & Siswa 12 & 62.2 & 77.7 & Tuntas / Meningkat \\
\hline 13 & Siswa 13 & 68.8 & 75.5 & Tuntas / Meningkat \\
\hline 14 & Siswa 14 & 80 & 75.5 & Tuntas / Meningkat \\
\hline 15 & Siswa 15 & 62.2 & 64.4 & Tuntas / Meningkat \\
\hline 16 & Siswa 16 & 62.2 & 62.2 & Tuntas / Meningkat \\
\hline 17 & Siswa 17 & 37.7 & 62.2 & Tuntas / Meningkat \\
\hline 18 & Siswa 18 & 66.6 & 62.2 & Tuntas / Meningkat \\
\hline 19 & Siswa 19 & 33.3 & 55.5 & Tuntas / Meningkat \\
\hline 20 & Siswa 20 & 22.2 & 44.4 & Tuntas / Meningkat \\
\hline Jumlah & $\mathbf{1 2 0 2 . 7}$ & $\mathbf{1 5 4 8 . 2}$ & Meningkat \\
\hline Rata-rata & $\mathbf{6 0 . 1 3 5}$ & $\mathbf{7 7 . 4}$ & Meningkat \\
\hline Ketuntasan & $\mathbf{1 5}$ & $\mathbf{1 8}$ & Meningkat \\
\hline & & $\mathbf{7 5 \%}$ & $\mathbf{9 0 \%}$ & Meningkat \\
\hline
\end{tabular}

Dari Tabel 5 dan 6 terlihat bahwa 4 orang siswa mengalami kenaikan nilai mencapai nilai 100 dan 5 orang siswa mengalami peningkatan nilai mencapai nilai 88.8-80, dan 5 orang siswa mengalami peningkatan nilai mencapai nilai 77.7-75.5 yang telah berhasil mengalami peningkatan nilai pada Siklus II hingga mencapai nilai $\mathrm{KKM}$ yaitu $\geq 60,4$ orang siswa yang mengalami peningkatan nilai mencapai nilai 60, akan tetapi juga terdapat beberapa siswa yang mengalami peningkatan nilai namun tetap belum mencapai KKM pada siklus II yaitu 
sebanyak 2 orang. Namun ada 2 orang yang mengalami penurunan nilai namun tidak sampai dibawah KKM.

\section{PENUTUP}

Berdasarkan hasil penelitian dan yang telah diuraikan di atas, maka dapat diuraikan beberapa kesimpulan sebagai berikut, hasil belajar siswa dengan menggunakan Media Audio pada Pembelajaran PPKn Tema di Kelas VIII SMP Negeri 1 Tigapanah Tahun Pelajaran 2018/2019 Tuntas secara Klasikal. Hasil belajar siswa meningkat setelah Menggunakan Media Audio pada Pembelajaran PPKn di Kelas VIII SMP Negeri 1 Tigapanah Tahun Pelajaran 2018/2019 siswa sudah meningkat.

\section{DAFTAR PUSTAKA}

Amri, Sofan. 2016. Pengembangan dan Model Pembelajaran dalam Kurikulum 2013. Jakarta : PT Prestasi Pustakaraya.

Aqib, Zainal dkk. 2016. Penelitian Tindakan Kelas. Bandung : Yrama Widya.

Arikunto, Suhardjono dkk. 2016. Penelitian Tindakan Kelas. Jakarta: PT Bumi Aksara.

Arikunto, Suharsimi. 2015. Dasar-dasar Evaluasi Pendidikan. Jakarta: PT Bumi Aksara.

Asra dan Sumiati, 2016. Metode Pembelajaran. Bandung: CV WACANA PRIMA

Baharuddin, Esa Nur Wahyuni. 2015. Teori Belajar dan Pembelajaran. Yogyakarta : Ar-Ruzz Media.

Hamalik, Oemar. 2016. Proses Belajar Mengajar. Jakarta : PT Bumi Aksara.

Hamdani. 2017. Strategi Belajar Mengajar. Bandung : CV Pustaka Setia.

Hamiyah, Nur. Muhammad Jauhar. 2014. Strategi Belajar Mengajar di Kelas. Jakarta : Prestasi Pustakaraya. 